All about Your Eyes 



\section{All about Your Eyes}

SHARON FEKRAT, M.D., FACS, AND

JENNIFER S. WEIZER, M.D., EDITORS

FOREWORD BY PAUL LEE, M.D., J.D.

ILLUSTRATIONS BY STANLEY M. COFFMAN

Duke University Press Durham and London 2006 
2nd printing, 2006

(C) 2006 Duke University Press

All rights reserved

Printed in the United States of

America on acid-free paper @

Designed by $\mathrm{CH}$ Westmoreland

Typeset in Minion by Tseng

Information Systems, Inc.

Library of Congress Cataloging-

in-Publication Data appear on

the last printed page of this

book. 